\title{
Evaluation by the end-users of disaster risk warnings in Brazil
}

\author{
Avaliação dos usuários de alertas de risco de desastres no Brasil
}

\author{
Silvia Midori Saito ${ }^{a}$ \\ Glauston Roberto Teixeira de Lima $^{b}$ \\ Mariane Carvalho de Assis Dias ${ }^{c}$ \\ aPesquisadora do Centro Nacional de Monitoramento e Alertas de Desastres Naturais - Cemaden, \\ São José do Campos, SP, Brasil \\ E-mail: silvia.saito@cemaden.gov.br \\ ${ }^{b}$ Pesquisador do Centro Nacional de Monitoramento e Alertas de Desastres Naturais - Cemaden, São \\ José do Campos, SP, Brasil \\ E-mail: glauston.lima@cemaden.gov.br \\ cPesquisadora do Centro Nacional de Monitoramento e Alertas de Desastres Naturais - Cemaden, \\ São José do Campos, SP, Brasil \\ E-mail: mariane.assis@cemaden.gov.br
}

doi:10.18472/SustDeb.v10n2.2019.24908

Received: 29/05/2019

Accepted: 19/08/2019

ARTICLE- VARIA

\begin{abstract}
Disaster risk warnings have been issued by the National Centre for Monitoring and Early Warning of Natural Disasters (Cemaden) to municipalities susceptible to floods and landslides in Brazil since December 2011. A survey of the end-users was developed in order to obtain an evaluation related to quality, anticipation and precision of the warnings. Using an explorative approach, a semi-structured questionnaire was available online to be filled in by the individuals responsible for receiving the warnings. The analysis of the results was supported by statistical techniques, to allow association among the variables. The majority of the users did not report difficulties in understanding the warning texts. However, they reported the inefficiency in receiving warnings by email and suggested that faster tools would be a better solution, i.e. a short message service. The improvements in the alerts could be informed by the results achieved in this survey.
\end{abstract}

Keywords: Brazilian early warning system; Warnings; Preparedness; Civil defense.

\section{RESUMO}

Desde dezembro de 2011, alertas de risco de desastres em escala nacional têm sido emitidos pelo Centro Nacional de Monitoramento e Alertas de Desastres Naturais (Cemaden) no Brasil para municípios suscetiveis a deslizamentos e inundações. Uma pesquisa foi realizada para se obter a avaliação dos usuários de tais alertas, em relação à sua qualidade, antecipação e precisão. A partir de uma abordagem exploratória, um questionário online semiestruturado foi disponibilizado para ser respondido pelos responsáveis em receberos alertas. A análise dos resultados da pesquisa foi apoiada por técnicas estatísticas para permitir a associação entre as variáveis. A maior parte dos usuários respondeu não ter dificuldades em entender o texto dos alertas. Entretanto, eles relataram que o recebimento dos alertas por e-mail é ineficiente e o uso de ferramentas mais ágeis, como, por exemplo, mensagens via celular, seria uma melhor solução. A implementação de melhorias no sistema de alertas pode ser orientada considerando a avaliação dos usuários obtida.

Palavras-chave: Sistema de alertas brasileiro; Alertas; Preparação; Defesa civil. 


\section{INTRODUCTION}

Disaster risk related to natural hazards affects the Brazilian population discretely, mainly due to different levels of exposure (NUNES, 2009). Almost 90\% of the natural disaster cost in Brazil, from 1991 to 2010 was related to floods, flash floods, and landslides, which translates to about 2,000 deaths, (CEPED, 2012). The data analysis of S2iD, the database of the National Civil Defense (SEDEC, 2019) shows that from 2011 to 2018, a total of 2,195 Brazilian municipalities declared a state of emergency or calamity due to disasters related to floods, landslides, storms or droughts. In world comparative terms, this does not constitute a higher incidence of disasters. However, their impacts including economic and human losses have been increasing, which does indicate the need for preventive measures against disasters in the country.

In particular, in January 2011, the mountainous region of Rio de Janeiro experienced the worst recent catastrophe in Brazil. In that same year, over than 1,000 people died due to the violent debris flows and flash floods that occurred after heavy rainfall (DOURADO et al. 2012; FRAIFELD and FREITAS, 2012). The Brazilian government, in a reactive response, defined some disaster risk management actions, in the same year.

First, it created a novel national agency to monitor disaster risk for the most frequently affected municipalities, i.e., "The National Centre for Monitoring and Early Warning of Natural Disasters (Cemaden, in Portuguese)." It is the federal agency in charge of the continuous monitoring of disaster risk and issuing warnings in Brazil. In addition, the Brazilian government supported the enhancement of the National Centre of Risk and Disasters Management (Cenad, in Portuguese), responsible for preparing populations for disasters (HORITA et al. 2017). Finally, a significant measure was the launching of the National Plan on Risk Management and Response to Natural Disasters (2012-2014), which allocated financial resources for mapping, prevention, monitoring and early warnings, and disaster response actions according to what was available in 2012 (GUTIÉRREZ et al, 2014).

In contrast to other countries, such as Japan and the United States, in Brazil the warnings are not issued directly to the population. There is a protocol established in 2012 (BRAZIL, 2012) that defined the flow of information between Cemaden and Cenad. Thus, the early warnings are sent by Cenad to the responsible entity in each municipality monitored by Cemaden, which are in general, municipal civil defense, and fire departments, in charge of warning the population.

The selection of the Brazilian monitored municipalities was based on databases of historical reports mainly from the National Civil Defense, the Institute for Technological Research of Sao Paulo State and the National Water Agency. The criteria considered included the high recurrence of disasters related to landslides and floods, resulting in casualties, damages and losses. Currently, Cemaden monitors 958 municipalities, which represent $17 \%$ of all Brazilian municipalities $(5,570)$. Since December 2011, this has been the modus operandi of part of the Early Warning System (hereafter EWS) in Brazil.

The warnings of the Cemaden currently consists the following contents: i) risk scenario, which describes the hazards that could affect the vulnerable area; ii) actual scenario, that contains information about the total amount of precipitation; iii) forecast, predicting the meteorological conditions in the following hours; iv) recommendations, drawing attention to the risk areas; and v) civil protection steps recommended by Cenad. In general, Cemaden alerts contain a map of risk areas, meteorological radar images, and graphs of precipitation, when available.

The creation of the alerts requires considerable technical and scientific knowledge, such as hydrological models development, rainfall thresholds for landslides and risk communication. Multidisciplinary teams with professional experts from Meteorology, Geodynamics, Hydrology, and Disasters experts evaluate the risk scenario and its prognosis to decide upon early warning issues. Cenad receives the alerts from Cemaden and transmits them to the state and municipalities responsible for the response actions.

Several improvements were made in Brazilian disaster risk management from 2012 to 2014, in the sense that more cities have become involved, risk area maps with high resolution have been produced, and several instruments have been installed to obtain data in situ (e.g., rain gauges, hydrological stations). Therefore, after the continuous advances of this system, the end-users have been consulted about the quality, timeliness and precision of the alerts of Cemaden. 


\section{EARLY WARNINGS SYSTEM (EWS)}

During recent years, the EWS discussion has become an important aspect of the local and national public policies for disaster risk management, as part of the global agendas, i.e. Hyogo and Sendai Frameworks, and Sustainable Development Goals of the 2030 Agenda. The early warnings must guarantee a timely response to disasters as well as reliability to permit taking actions, such as preparedness and response (UNEP, 2012).

Specifically, in relation to the recommendation of learning to live with risks (UNISDR, 2009), the EWS are a tool that has been implemented by many countries and municipalities in order to prevent human and material losses (GOLNARAGHI, 2012). The effectiveness of early warnings for reducing deaths and damages caused by floods, winds and volcanic activity was recognized by Davis (2019) as one of the success measures of recent decades.

There is an erroneous tendency to consider EWS merely as technologies related to the weather forecast. According to the United Nations for Disaster Risk Reduction - UNISDR (2017) EWS is defined as "an integrated system of hazard monitoring, forecasting and prediction, disaster risk assessment, communication and preparedness activities systems and processes that enables individuals, communities, governments, businesses and others to take timely action to reduce disaster risks in advance of hazardous events." It is possible to perceive a change in perspective of the concept proposed by UNISDR in 2009. The previous version had a more sectorial approach while the current concept is systemic and multisector.

Additionally, the UNISDR states that there are four key elements that should be considered in a peoplecentred EWS: (i) disaster risk knowledge, (ii) monitoring, (iii) dissemination and communications, and (iv) preparedness. This approach implies that the system works in consonance with other fields of knowledge, such as engineering, social sciences and natural sciences. In conclusion, EWS is multidisciplinary in essence (Basher, 2006; UNEP, 2012).

A systematic people-centred EWS means empowering individuals and communities to act in sufficient time and manner to reduce human, environmental and material losses (UNISDR, 2006). In other words, EWS empowers people to take action prior to a disaster, as well as the vulnerable sectors and groups to mitigate the potential losses and damages from hazards (MASKREY, 1997, UNEP, 2012). The involvement of the population in an EWS could guarantee over time a more sustainable system (MACHERERA and CHIMBARI, 2016), in the sense of encouraging participation in a way that empowers vulnerable sectors and social groups to mitigate the potential losses and damages from impending hazard events

It implies the coordinated participation of many different organizations committed to the peoplecentred concept (BASHER, 2006). Therefore, as a system all components must act together to guarantee the success of the whole structure (DUTTA and BASNAYAKE, 2018). According to Sorensen (2000) the EWS bring together multiple institutions and organizations to communicate warnings to all relevant stakeholders, e.g. scientific, civil authorities, technical, media and the public.

\subsection{BRIEF CONTEXT OF EWS IN BRAZIL}

There is an integral relationship between the four elements of the EWS, which means that if any part does not work it could affect the whole system (UNEP, 2012; GOLNARAGHI, 2012, COOLS et al, 2016, SAITO, 2018). For instance, an early warning will be effective with the understanding of communities and their response in case of a disaster. It necessitates groundwork of risk communication (i.e. to analyze the appropriate language for the population) and preparedness (i.e. evacuation routes and safe areas pre-defined and well known by the users).

Some distinct efforts were made in the past to develop EWS in Brazil, but in this aspect, it has been progressing, especially over the past decade. At the federal level, Cemaden installed the observational network composed of 4750 automatic rain gauges, 9 meteorological radars and almost 300 hydrological stations (HORITA et al, 2017). As regards preparedness, Cenad (2018) developed a manual about 
contingency plans. At the state level, new centers were established or enhanced, such as the Centre for Monitoring and Early Warning of Natural Disasters (Cemaden/RJ) Rio de Janeiro State and the Centre Integrated for Disaster and Risk Management (CIGERD) at Santa Catarina State (CIOTTA and PANCERI, 2018, FRANK et al, 2019).

The first basis of disaster risk knowledge developed in the country was due to the efforts of some areas of academia, mainly from geology (AUGUSTO FILHO and WOLLE, 1996; TATIZANA et al. 1987; MACEDO et al, 2007), geography (HERRMANN et al, 1994; PELLERIN et al. 2002; FERNANDES et al. 2001), and social sciences (ALVES, 2006; MARANDOLA and HOGAN, 2005; VALENCIO, 2009).

These efforts contributed to a better understanding of hazards and vulnerabilities of the exposed populations. According to Rodrigues et al (2015) disaster studies have been emerging in Brazil, especially during the last few years, which may be related to the already existing debate about disasters in the country, or to the greater frequency of extreme events, or even the IPCC Fourth Assessment Report publication.

In relation to the second key element of EWS, activities related to disaster risk monitoring at the national level began at the end of 2011, after the disaster in the mountainous region of Rio de Janeiro State, as explained in the item above. However, it should be noted that there were state initiatives to monitor floods, such as in São Paulo (SAISP - São Paulo Flood Alert System) and in Santa Catarina (CEOPS - Operation Centre Flood Alert System), in 1977 and 1984, respectively (MARCHEZINI et al, 2017b). At the municipal level, the Alerta Rio in the Rio de Janeiro municipality was created in 1996 to warn populations about heavy rainfall. (DOLIF et al, 2013; CALVELLO et al, 2014)

Since January 2017, the dissemination of warnings using short message service (SMS) has been adopted by the National Civil Defense in Santa Catarina as a state pilot. During 2018 and 2019, this free service was also available for the Espirito Santo, Sergipe, Mato Grosso do Sul, Goias, Rio de Janeiro, Sao Paulo, Rio Grande do Sul, and Parana States as well as for the Federal District (Portal Federativo, 2019). The service provides SMS warnings about the possibility of disasters related to floods, landslides, hail, and windstorms to users of this free service. The user must send a message to 40199 to receive the SMS free of charge, stating the Postal Code of the municipality of interest.

Although the SMS service availability has increased as well as the number of monitoring institutions, access to information about risks and prevention has not reached the entire population. Practices such as simulations and training are restricted to a few communities, mainly those most affected by disasters (e.g. Blumenau at Santa Catarina State; Campos do Jordao at Sao Paulo State; Nova Friburgo at Rio de Janeiro State). There is a need for instruments that permit the communication between the population at-risk and public managers (SORIANO and HOFFMANN, 2016).

The preparedness phase in Brazil is mainly attributed to civil defense, whose institutional vulnerability limits its ability to engage in prevention and response actions. Valencio and Valencio (2011) attributed the difficulties faced by defense civil in the country to three main reasons: i) lack of deep knowledge about the socio-environmental connections that produced the multiple risks, and resulting disasters; ii) deficit of inter-sectorial coordination involving the public and private sectors to mitigate the disaster effects and iii) lack of interaction with the civil society to build resilient processes together in everyday life.

Besides, Brazilian civil defense has a military root, influencing its reactive posture (VALENCIO, 2014). These aspects explain the fragility of preparedness actions in Brazil and therefore the EWS in the country could be characterized as "last-mile" meaning a top-down approach: the population interested in the warnings does not have any direct participation or involvement in the EWS (MARCHEZINI et al. 2017a). 


\section{DATABASE AND METHODOLOGIES}

\subsection{THE DATABASE}

The database used in this paper to perform analyses in order to obtain a comprehensive overview of how users evaluate Cemaden warnings is for the most part made up of responses to an online questionnaire. In this questionnaire, 27 questions were raised concerning civil defense infrastructure and the assessment of warnings issued by Cemaden. Among the 27 questions, 23 are multiple choice questions and 4 are open-ended.

The survey was conducted between December 2016 and March 2017. A mailing list of the users from the 958 municipalities monitored by Cemaden was organized. The source of the contacts was the S2iD (Integrated Disaster Information System) (BRAZIL, 2017), provided by Cenad. Municipal civil defenses use this system to register occurrences of disasters as well as to request federal resources. Consequently, it is considered the most up-to-date database of contacts. In many cases, there was more than one responsible user per municipality and for this reason a list of 1653 contacts were defined.

Three invitations to reply to the questionnaire were sent on December 22, January 21, and March 11, aiming to reach a larger number of participants in order to reinforce the survey results. At the beginning of the questionnaire, some clarifications on ethical aspects of the survey were presented to the participants:

I. No analysis would be made based on individual responses.

II. Results would be disseminated by regions or categories separately.

III. Access to the data will be restricted to the research team; thus, anonymity and confidentiality were guaranteed to the contributors.

Subsequently, the preliminary results of the survey were presented at the 1st National Seminar of Evaluation of Cemaden Alerts (I SNAC) on April 2017. During this seminar, topics related to the survey (i.e. quality, anticipation and precision of the warnings) were debated in the round tables. The main discussions were summarized and included in the annals of the event (Cemaden, 2017), and also used as an additional information source of this study.

It is noteworthy that in this paper the term end-users defines those who receive warnings directly from Cenad, i.e. municipal or state civil defense, firefighters departments and municipal secretariats of environment (as mentioned in a previous section, warnings issued by Cemaden are first sent to Cenad, and then to end-users).

\subsection{QUANTITATIVE ANALYSIS}

The database with the questionnaire responses was stored in electronic spreadsheets so as to allow quantitative analysis most of which was univariate analysis using basic statistical concepts such as sample averages (here it is considered that some of the 27 questionnaire questions could be treated as variables). Univariate analysis was applied to aspects such as: i) period of professional experience of the responders; ii) hazards that affect the municipality; iii) useful applicability of the response actions; and iv) anticipation and applicability of the warnings.

A bivariate analysis was also performed. To this end, Bivariate Cross Tabulation (BCT) was applied. This technique is widely used in social sciences studies (Johnson et al. 2019; WILDEMUTH, 2016; KAPLOWITZ, 2000) in order to understand how two different variables are related to each other. In the present study, BCT was used to correlate users' assessment on Cemaden warnings usefulness with their experience in civil defense activities (see Table 3 in the section Results). 


\subsection{QUALITATIVE ANALYSIS}

Regarding qualitative analysis, the approach called Structuring Content Analysis (KULATUNGA, 2007; HSIU-FANG, 2005) was applied. One of the tools defined by this approach is word count (or textual analysis). So, a word count was performed to ascertain how often a given word was quoted by the participants in the answers to the question "Do you have any suggestion for the improvement of the warnings issued by Cemaden?" The word count results were computed according to the following four response categories:

I. containing the words SMS and Cell Phone;

II. containing the word Anticipation;

III. containing the words WhatsApp and App;.

IV. containing the words Equipment and Rain Gauges.

\section{RESULTS}

During the period the form was available, 326 respondents from 283 municipalities participated in the survey, corresponding to $30 \%$ of the municipalities monitored by Cemaden (Figure 1). One reason for the low number of participants could be due to problems related to typing errors such as the e-mail addresses which were obtained from S2iD or to full mailboxes (305, in total). In addition, some respondents had answered that they are not currently working for the civil defense. New mayors took office on January 2017 and it is likely this has meant as a consequence some changes among their staff, which contributed to the low adhesion of the survey.

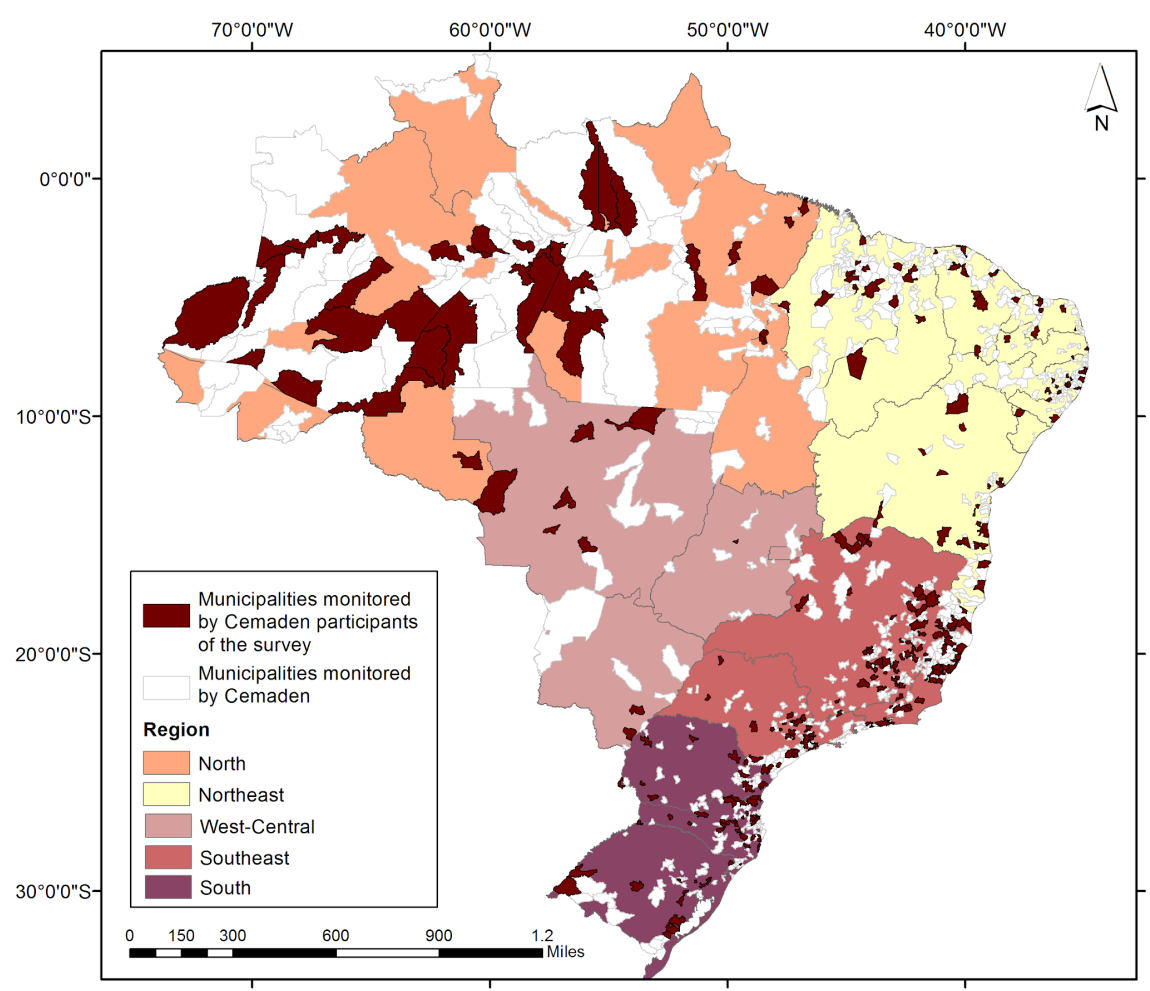

Figure 1 | Municipalities' participants of the survey per Brazilian region.

Source: prepared by the authors. 
The civil defense at the municipal level is extremely vulnerable to political changes in Brazil (VALENCIO, 2009; LONDE et al, 2015; MARCHEZINI et al, 2017b). According to the Municipal Basic Information Survey - MUNIC, from the 5570 Brazilian municipalities, only 2,809 reported the existence of municipal civil defense in 2013 (IBGE, 2013). On the other hand, only 1\% of municipalities have permanent position career of civil defense agent. In this scenario, it is common to observe transfers of civil defense technicians to other sectors of municipal governments. This may help to understand the constant interruption of services and the lack of continuity in civil defense activities at the municipal level. The most recent MUNIC survey showed that in 2017 there was an increase of municipal civil defense, with a total of 3,826 municipalities (IBGE, 2017), however the question about career issues was removed from the survey, which made trend analysis impossible.

Taking into account the number of monitored municipalities in each Brazilian region, the majority of responders were from the South municipalities $(36,36 \%)$ and the Southeast ones $(35,91 \%)$; the smallest was from Northeast region (Table 1). There were no participants in the survey from Acre, Amapa and Rondonia States, all of them from the North region. It is relevant to consider that those states have a minor number of monitored municipalities in comparison to others. In absolute numbers, the majority of the respondents were from the Southeast region; however, it is important to emphasise that the number of municipalities monitored by Cemaden in this region is higher than in the others.

Table 1 | Percentage of municipalities' participants of the survey monitored by Cemaden.

\begin{tabular}{|c|c|c|c|c|}
\hline Region & State & $\begin{array}{l}\text { Total of responses } \\
\text { per State }\end{array}$ & $\begin{array}{l}\text { Total of municipalities } \\
\text { monitored by Cemaden }\end{array}$ & $\begin{array}{c}\% \text { of municipalities monitored by Cemaden } \\
\text { participants of the survey }\end{array}$ \\
\hline \multirow{4}{*}{$\begin{array}{l}\text { I } \\
\stackrel{5}{5} \\
\stackrel{0}{\backsim}\end{array}$} & Parana & 12 & 36 & 33,33 \\
\hline & $\begin{array}{l}\text { Rio Grande } \\
\text { do Sul }\end{array}$ & 14 & 39 & 35,90 \\
\hline & $\begin{array}{l}\text { Santa } \\
\text { Catarina }\end{array}$ & 30 & 79 & 37,97 \\
\hline & Total & 56 & 154 & 36,36 \\
\hline \multirow{4}{*}{ 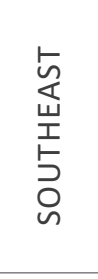 } & Espirito Santo & 27 & 67 & 40,30 \\
\hline & Minas Gerais & 46 & 143 & 32,17 \\
\hline & Rio de Janeiro & 10 & 16 & 62,50 \\
\hline & São Paulo & 33 & 97 & 34,02 \\
\hline & Total & 116 & 323 & 35,91 \\
\hline \multirow{8}{*}{$\begin{array}{l}I \\
I \\
\text { ơ } \\
\bigcirc \\
Z\end{array}$} & Acre & 0 & 7 & 0,00 \\
\hline & Amapa & 0 & 2 & 0,00 \\
\hline & Para & 9 & 39 & 23,08 \\
\hline & Amazonas & 19 & 54 & 35,19 \\
\hline & Rondonia & 0 & 2 & 0,00 \\
\hline & Roraima & 2 & 3 & 66,67 \\
\hline & Tocantins & 2 & 10 & 20,00 \\
\hline & Total & 32 & 117 & 27,35 \\
\hline \multirow{4}{*}{ 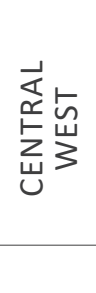 } & Goias & 1 & 9 & 11,11 \\
\hline & Mato Grosso & 6 & 15 & 40,00 \\
\hline & $\begin{array}{l}\text { Mato Grosso } \\
\text { do Sul }\end{array}$ & 2 & 7 & 28,57 \\
\hline & Total & 9 & 31 & 29,03 \\
\hline
\end{tabular}




\begin{tabular}{|c|c|c|c|c|}
\hline \multirow{10}{*}{ 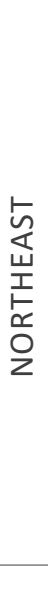 } & Alagoas & 3 & 24 & 12,50 \\
\hline & Bahia & 18 & 47 & 38,30 \\
\hline & Ceara & 10 & 41 & 24,39 \\
\hline & Maranhao & 12 & 84 & 14,29 \\
\hline & Paraiba & 2 & 15 & 13,33 \\
\hline & Pernambuco & 14 & 66 & 21,21 \\
\hline & Piaui & 4 & 25 & 16,00 \\
\hline & $\begin{array}{l}\text { Rio Grande } \\
\text { do Norte }\end{array}$ & 6 & 28 & 21,43 \\
\hline & Sergipe & 1 & 3 & 33,33 \\
\hline & Total & 70 & 333 & 21,02 \\
\hline
\end{tabular}

Sources: Cemaden (2019), data survey organised by the authors.

Male respondents were the majority (83\%) in this survey, which clearly evidences the low participation of women in Brazilian civil defense leadership positions. In regard to the function of the participants, $59 \%$ were municipal civil defense coordinators and the remaining ones were placed in technical or administrative positions. In view of the period of experience in civil defense, $44 \%$ affirmed that they had over than 5 years' service, 28\% had between 3 and 5 years, 21\% had from 1 to 3 years, and $7 \%$ had less than 1 year.

There was an open question in the survey in order to identify other hazards that affect the municipalities, differently from what Cemaden monitors currently. The results showed that windstorm was the most quoted by the participants, with $27 \%$ of the answers, followed by hail $(16 \%)$, coastal and linear erosion $(13 \%)$, wildfire (12\%) and drought (12\%). The results are presented by region according to Table 2 .

Table 2 | Hazards quoted by the participants.

\begin{tabular}{|c|c|c|c|c|c|c|}
\hline Hazard & North & Northeast & South & Southeast & Central-West & Total \\
\hline COASTAL AND LINEAR EROSION & 3 & 3 & 0 & 3 & 2 & 11 \\
\hline INFRASTRUCTURE COLLAPSE & 0 & 3 & 0 & 0 & 0 & 3 \\
\hline DROUGHTS & 3 & 3 & 2 & 2 & 0 & 10 \\
\hline HAILS & 0 & 0 & 11 & 3 & 0 & 14 \\
\hline SEISMIC TREMORS & 0 & 2 & 0 & 0 & 0 & 2 \\
\hline WINDSTORMS & 5 & 0 & 20 & 15 & 0 & 23 \\
\hline TECHNOLOGICAL DISASTERS & 0 & 2 & 0 & 2 & 0 & 3 \\
\hline TORNADOES & 0 & 0 & 7 & 2 & 0 & 9 \\
\hline WILDFIRES & 4 & 2 & 2 & 2 & 0 & 10 \\
\hline TOTAL & $\mathbf{1 2}$ & $\mathbf{1 5}$ & $\mathbf{2 9}$ & $\mathbf{1 8}$ & $\mathbf{2}$ & \\
\hline
\end{tabular}

Source: data survey organized by the authors. 
In relation to receiving the warnings in sufficient time, $50 \%$ replied positively, $33 \%$ sometimes in time and $17 \%$ as negatively. The most cited observations that the participants had written down were in relation to the warning delays, for instance: i) the flash flood alerts were delayed, in some cases even being received after the occurrence; ii) the municipal civil defense did not have enough staff to cover all the risk areas during the critical period; iii) disasters during the early hours made it difficult to evacuate the population.

In regards to the applicability of the warnings, 55\% answered that they were useful for civil defence activities, $20 \%$ as partially useful, $11 \%$ as negatively and $14 \%$ had no opinion. Furthermore, by using a cross-tabulation analysis, it was possible to verify that the professionals performing civil defence activities for longer tended to consider the usefulness of the warning more positively (Table 3 ). The group of respondents with over 5 years of experience also evaluated the warnings as being to some extent partially important, and the reason quoted were: i) even with the warning issued, it was not necessary to evacuate the population from risk areas; ii) the warning is received a few minutes before the beginning of the first occurrences; iii) difficulties to receive warning by e-mail due to the Internet connection or electric power failure.

Table 3 | The usefulness of the warning considering the period of experience in civil defence activities.

\begin{tabular}{|c|c|c|c|c|c|c|c|c|}
\hline $\begin{array}{c}\text { PERIOD OF } \\
\text { EXPERIENCE IN } \\
\text { CIVIL DEFENCE } \\
\text { ACTIVITIES }\end{array}$ & \multicolumn{2}{|c|}{ YES } & \multicolumn{2}{c|}{ NO } & \multicolumn{2}{c|}{ PARTIALLY } & \multicolumn{2}{c|}{ NO OPINION } \\
\cline { 2 - 12 } & Freq & $\%$ & Freq & $\%$ & Freq & $\%$ & Freq & $\%$ \\
\hline Less than 1 year & 9 & 5,08 & 2 & 5,56 & 8 & 12,12 & 5 & 11,11 \\
\hline $1-3$ years & 33 & 18,64 & 5 & 13,89 & 12 & 18,18 & 18 & 40 \\
\hline $3-5$ years & 49 & 27,68 & 11 & 30,56 & 16 & 24,24 & 13 & 28,89 \\
\hline over 5 years & 86 & 48,59 & 18 & 50 & 30 & 45,45 & 9 & 20 \\
\hline No answer & 2 & 1 & 0 & & 0 & & 0 & \\
\hline Total & 179 & 100 & 36 & 100 & 66 & 100 & 45 & 100 \\
\hline
\end{tabular}

Source: data survey organized by the authors.

To the question about the warning useful applicability specifically for response actions, $64 \%$ answered positively, $23 \%$ partially and $13 \%$ replied negatively. The justifications among those who answered 'no' or 'partially' were: i) the warnings were not delivered within enough time to mobilise the teams in the field; ii) the warnings were generic and did not specify the priority areas for the first response actions; and iii) difficult access to the warning received by e-mail due to an internet connection failure. The higher indexes related to internet problems were revealed in the North region (78\%) suggesting precarious infrastructure in this region of the country. By contrast, in the South region only $33 \%$ of the respondents had Internet problems.

Precise indication of when and where the disaster will occur remains the greatest challenge for EWS experts (SEIBOLD, 2013). For instance, flash floods are hard to predict due to their rapid formation and the alterations of the hydrological response of catchments (ACOSTA-COLL et al, 2018). Besides, issues related to warning dissemination could enhanced the delay for receiving the re also present in other countries in the world, such as Egypt, where telecommunication and mobile phone network is still too limited (COOLS et al, 2016).

In Brazil, as previously demonstrated in this paper, the civil defence activity encounters significant institutional vulnerability that affects its performance. In view of this, it is possible to understand the justifications quoted above by the participants. The workforce is restricted to a very few professionals in the municipalities, that work concurrently on many activities. Therefore, in these cases, the early warnings must be received with the maximum anticipation in order to allow the mobilization of the 
teams in the field. Additionally, the warnings must be as accurate as possible, indicating the priority disaster risk areas since the teams are reduced. Finally, many civil defense professionals reported the use of their personal cell phones, with limited internet data plan, hindering the warning download by e-mail.

There was a specific question in the questionnaire related to the essential information in the current model of the warning issued by Cemaden. The current trend nowadays suggest towards conciseness, e.g. Short Message Service. As a result, one of the main concerns of Cemaden staff is to reduce the alert text due to the criticisms of its verbosity, in some cases with more than 5 pages.

The participant could select more than one option because it was a multiple choice. The results in order of the most cited were i) maps of landslide and flood risk areas (252); ii) recommendations of civil defense actions based on Cenad principles (247); iii) worsening of risk scenarios (243); iv) precipitation graphs (239); v) meteorological radar images (196). It is possible to note that there were no significant differences among the figures, which may suggest that the contributors considered all information as relevant for the warning.

The participants also answered about the warnings' dissemination at the local level. The most used resources were i) social networks such as Facebook and Twitter (25\%); ii) phone calls to the community leaders or the civil defense community nucleus (19\%); iii) the use of apps, e.g., WhatsApp (17\%); iv). Different sources were also quoted by the applicants, for instance community radio, speakers placed on church steeples, health social workers and staffed warning boats. In terms of proportion, $43 \%$ of the participants quoted the visits in loco and 39\% stated that they use the local radio for the warnings' dissemination. Figure 2 presents the results by Brazilian region. It is possible to identify that the main sources are compatible with the characteristics of the hazards that affect the regions. For example, the gradual floods that occur in the North region are slow, which allows the civil defense to use the local radio or even to go in person to warn the risk areas' population. The participants from the Central West region did not indicate any resources for dissemination at the local level.

Disaster response demands a synergized performance from different areas of public administration. In this sense the respondents answered that they share the alerts with other municipal fields; the most cited were the mayor's office (28\%), infrastructure (25\%), and education secretary (15\%), and in a minor proportion, it was also mentioned that they contacted public security, housing, agriculture, health, tourism and transport secretaries. Some institutions were named by the responders such as police, civil defense volunteers and sanitary surveillance.

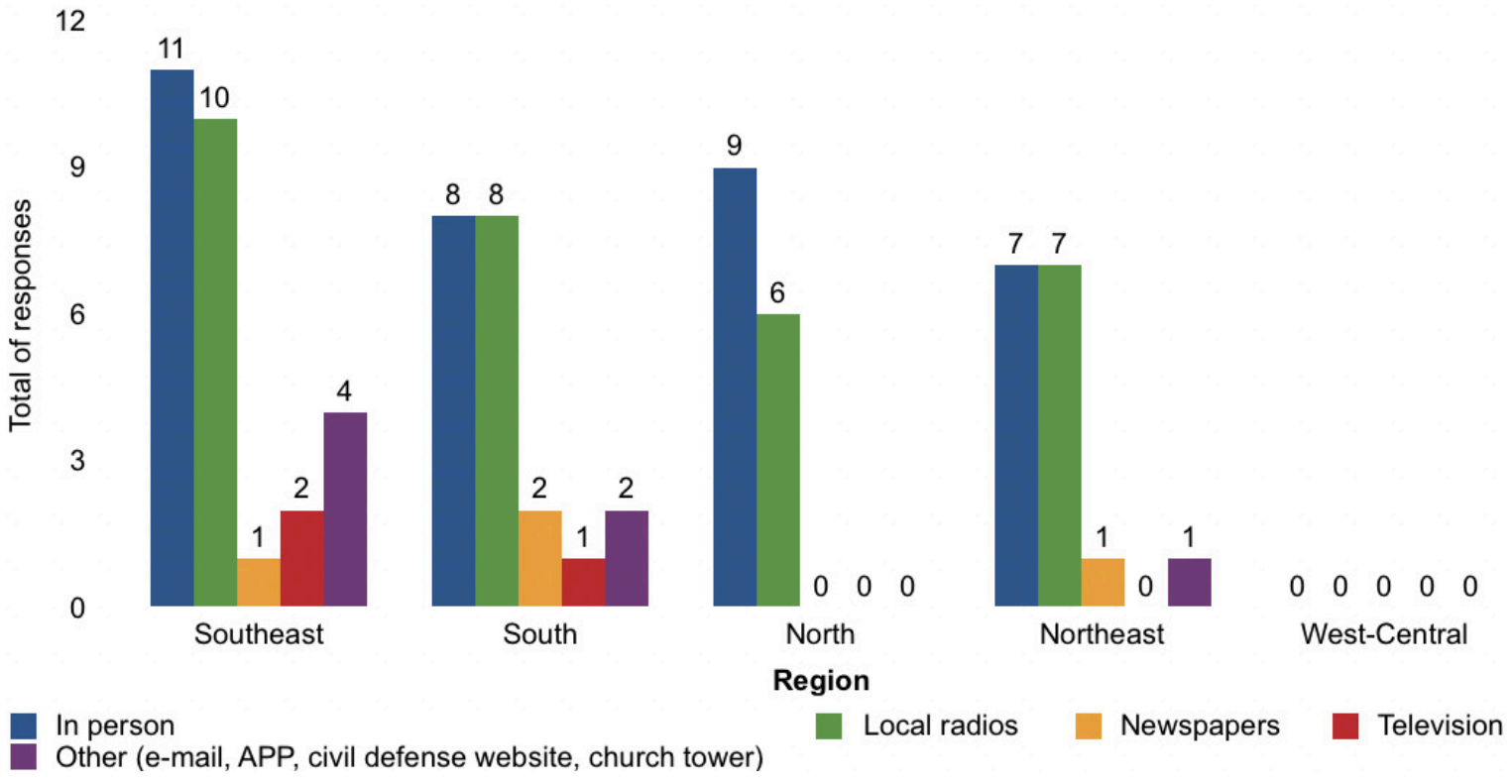

Figure 2 | Dissemination of the warnings at the local level.

Source: data survey organized by the authors. 
The participant was able to suggest some warning improvements in the last question of the survey. The main suggestions were related to enhancing and increasing of disaster warnings, mainly flash floods, allowing response actions at the local level. Another aspect was associated with receiving the early warnings through SMS or phone calls, since e-mails are inefficient due to internet connection problems during rainy situations or early morning occurrences.

The main suggestions for EWS improvements were identified by a qualitative approach using textual analysis. After reading the answers for the question: "Do you have any suggestions for the improvement of the warnings issued by Cemaden?" the answers were classified into four categories, even including the misspelled words due to typing errors, considering that it was an open question (Table 4).

The categories associated with the cell phone incoming alerts by i.e. 3 and 4 in supra, were the most quoted by the participants of the survey, because Internet access is unreliable during their normal external activities, such as technical inspections. Another aspect mentioned was the problem related to the timing of receiving the warnings, with 21 answers. The difficulties were the lack of internet access in remote areas and receiving the warning after the disaster occurrence. Finally, there were also identified 8 answers that underlined the need for observational network improvements, with rain gauges or hydrological station installation.

Table 4 | Suggestions for the EWS improvement according to the end-users.

\begin{tabular}{|c|c|c|}
\hline Categories & Related words (including typing error) & Total of quotations \\
\hline Timeliness & Timing, delay, lack of internet access & 21 \\
\hline $\begin{array}{c}\text { Network } \\
\text { observational }\end{array}$ & Rain gauges, hydrological stations & 8 \\
\hline Cell phone & Cell phone messages, SMS & 50 \\
\hline App for smartphones & $\begin{array}{c}\text { WhatsApp/WhatsApp/WhatsApp, Telegram, message } \\
\text { from App }\end{array}$ & 37 \\
\hline
\end{tabular}

Source: data survey organized by the authors.

The respondents asked for training, especially related to managing environmental data, e.g. precipitation and river levels, because there are many websites offering real time data, such as Cemaden, SAISP and CEOPS. Brazilian civil defense workers are mainly composed of the military, firefighters, and civil guards, in other words, professionals without the technical background to analyze this data. It is a direct consequence of the institutional vulnerability that characterizes the civil defense in the country. The professionals are in charge of different activities in the municipality and there is a lack of trained technical staff, mainly those responsible for disaster prevention actions (GANEM, 2012).

The results of this survey were presented to the inaugural National Seminar of Evaluation of Cemaden Warnings - SNAC, April 4-6 2017, São Jose dos Campos, Sao Paulo State, Brazil. The seminar audience were 209 people from 19 Brazilian states and the Federal District. It was an opportunity to share the results and to collect additional contributions. For example, many participants reported the need for official recognition and consequent career improvement for civil defense workers. They supported the statement by citing the contribution to the permanency of professionals in their durability. In consequence the segment would be enhanced in municipal and state governments. The participants of the seminar also suggested a closer relationship between Cemaden and civil defense, with a direct channel to clarify doubts about early warnings, rainfall data, and other technical subjects.

Another point discussed during the SNAC was the difficulties experienced by the users that received warnings from institutions in addition to Cemaden. Some state or municipal institutions issue early warnings (e.g., AlertaBlu, INEA, Epagri-Ciram), which could cause some confusion to recipients. It is important to note that some of these entities were created before Cemaden establishment. Due to the lack of a national coordination, the institutions issue warnings using different procedures and risk levels (MARCHEZINI et al, 2017b). 


\section{CONCLUSION AND RECOMMENDATIONS}

This study was developed in order to obtain an overview of the end-user's evaluation of the Cemaden warnings. In regard to the four features of an EWS as stated by UNISDR (2017), the findings could support mainly the alert dissemination and communication as well as preparedness actions.

The survey presented a reduced percentage of responders, around $30 \%$ of the municipalities monitored by Cemaden. It demonstrated the need for improving the fragile database of contacts from the civil defense system. The use of institutional instead of personal e-mail or cell phone could be an option in order to maintaining permanent contact of the municipalities. In this regard, reduction of institutional vulnerability of the civil defense system must be a priority.

The majority of the respondents declared that the alerts are useful for civil defense actions. However, a significant proportion of the participants considered that the warnings did not support their activities due the lack of anticipation, mainly flash floods alerts, and nomination of the priority areas for attention. These results show the importance of Cemaden continuously improving disaster risk scenarios for the early warnings, by pointing out the vulnerable areas of the municipalities. In a complementary way, it is also important the knowledge of risk areas by the municipal civil defence professionals and the communication strengthening with the monitoring and research institutions.

After the conclusion of this survey and analysis, a number of recommendations can be made which could lead to impacts for the Brazilian EWS:

- re-thinking the out-of-date list of contacts from S2iD, since it is the main information source used by institutions such as Cenad and Cemaden;

- reassessment of the current protocol between Cemaden and Cenad, especially the workflow and the warning sending and receiving process;

- providing trainings focused on environmental data analysis for hazard monitoring, ideally jointly with universities and municipal and state monitoring institutions;

- stimulating the dialogue among the monitoring institutions in order to define protocols for issuing warnings in Brazil.

The findings of this study reveal that the warnings for achieving the goal of saving lives, it is crucial that the warnings incorporate as a system the four features of an EWS (i.e. disaster risk knowledge, monitoring, dissemination and communications, and as well as preparedness). This also requires efforts towards the communication between the stakeholders and an effective participation of the vulnerable communities. In conclusion, this type of survey should be frequently conducted in order to improve the dissemination and communication of the alerts, considering the end-user participation.

\section{ACKNOWLEDGMENTS}

This work was supported by the National Centre for Monitoring and Early Warning of Natural Disasters (Cemaden), which provided the infrastructure to maintain the online form. No additional sources were included to develop this work. The authors would like to thank Eduardo Fávero Pacheco da Luz for his help with the online survey. We also thank to Tiago Molina Schnorr from the National Centre of Risk and Disasters Management (Cenad) and all anonymous participants in the survey. 


\section{REFERENCES}

ACOSTA-COLL, M. B.; BALLESTER-MERELO, F., MARTINEZ-PEIRÓ, M., \& I, HOZ-FRANCO. Real-time early warning system design for pluvial flash floods - A review. Sensors, v. 18, n. 7, p. 2255, 2018.

ADHIKARI, B. R.; SITOULA, N. R., Community based flash flood early warning system: a low-cost technology for Nepalese mountains. Bulletin of the Department of Geology, p. 87-92, 2018.

ALVES, H. P. d. F. Vulnerabilidade socioambiental na metrópole paulistana: uma análise sociodemográfica das situações de sobreposição espacial de problemas e riscos sociais e ambientais. Revista Brasileira de Estudos de População (Impresso), Volume 23, pp. 43-59, 2006

AUGUSTO FILHO, O. \& WOLLE, C. M., Cartas de risco de escorregamentos: uma proposta metodológica e sua aplicação no município de Ilhabela, SP. Solos e Rochas, Volume 1, pp. 45-62., 1996.

BASHER, R., Global early warning systems for natural hazards: systematic and people-centred. Philosophical Transactions of the Royal Society of London, Volume 364, pp. 2167-2182, 2006.

BAUDOIN, M. et al. From Top-Down to "Community-Centric" Approaches to Early Warning Systems: Exploring Pathways to Improve Disaster Risk Reduction Through Community Participation. International Journal of Disaster Risk Science, Volume 7, pp. 163-174., 2016

BRAZIL, 18/12/2013. Joint Ordinance no148. s.I.:s.n

BRAZIL, 19/10/2012, Diário Oficial da União, n. 203, ISSN 1677-7042, p. 26. Available at: https://www.jusbrasil. com.br/diarios/41582182/dou-secao-1-19-10-2012-pg-26 Accessed 9 January 2019

BRAZIL, 2005. DECRETO № 5.376 DE 17 DE FEVEREIRO DE 2005. Available at http://www.planalto.gov.br/ ccivil_03/_Ato2004-2006/2005/Decreto/D5376.htm Accessed 7 November 2017

CALVELLO, M. et al. The Rio de Janeiro early warning system for rainfall-induced landslides: Analysis of performance for the years 2010-2013. International Journal of Disaster Risk Reduction, Volume 12, pp. 3-15., 2015

CEMADEN - Centro Nacional de Monitoramento e Alertas de Desastres Naturais, 2017. Anais do I Seminário Nacional de Avaliação de Alertas do Cemaden. [Online] Available at: http://www.Cemaden.gov.br/wp-content/ uploads/2017/04/Anais-do-I-Semin\%C3\%A1rio-Nacional-de-Avalia\%C3\%A7\%C3\%A3o-dos-Alertas-do-Cemaden. pdf [Accessed 15 September 2018.

CEMADEN - Centro Nacional de Monitoramento e Alertas de Desastres Naturais, 2019. Municípios Monitorados. Available at: http://www.Cemaden.gov.br/municipios-monitorados-2/. Accessed 1 June 2019.

CENAD - Centro Nacional De Gerenciamento De Risco E Desastres. Manual de Planos de Contingência para Desastres de Movimentos de Massa. 2018. Available at: http://mi.gov.br/documents/3958478/0/2018.11.30++Manual+Plancon+Mov+de+Massa.pdf/58cd7ca2-7cc3-456f-8c46-e2439ddae98d Accessed 4 January 2019

CEPED -CENTRO UNIVERSITÁRIO DE ESTUDOS E PESQUISAS SOBRE DESASTRES. Atlas Brasileiro de Desastres Naturais. Florianópolis: UFSC., 2012

CIOTTA, A. L.; PANCERI, R. Aviação De Defesa Civil Em Santa Catarina: Importante Ferramenta Na Gestão De Riscos E Desastres. Sociedade, Segurança e Cidadania, p. 49., 2018. Available at: http://sites.unisul.br/nesc/wpcontent/uploads/2018/10/nesc_livro-3.pdf\#page=49

COOLS, J.; INNOCENTI, D.; O'BRIEN, S. Lessons from flood early warning systems. Environmental Science \& Policy, v. 58, p. 117-122, 2016.

CUMISKEY, L., WERNER, M., MEIJER, K., FAKHRUDDIN, S. AND HASSAN, A., "Improving the social performance of flash flood early warnings using mobile services", International Journal of Disaster Resilience in the Built Environment, Vol. 6 No. 1, pp. 57-72. 2016 https://doi.org/10.1108/IJDRBE-08-2014-0062, 2016.

DAVIS, I. Reflections on 40 years of Disasters, 1977-2017. Disasters, v. 43, p. S61-S82, 2019. 
DE VAUS, D. Surveys in social research. Routledge, 2013.

DOLIF, G. et al. Resilience and brittleness in the ALERTA RIO system: a field study about the decision-making of forecasters. Natural Hazards (Dordrecht Online), February, 65(3), pp. 1831-1847, 2013.

DOURADO, F., ARRAES, T. C. SILVA, M. F.. O Megadesastre da Região Serrana do Rio de Janeiro - as Causas do Evento, os mecanismos dos Movimentos de Massa e a Distribuição Espacial dos Investimentos de Reconstrução no Pós-Desastre. Anuário do Instituto de Geociências - UFRJ, December, 35(1), pp. 43-54, 2012

DUTTA, R. BASNAYAKE, S. Gap assessment towards strengthening early warning systems. International Journal of Disaster Resilience in the Built Environment, 21 Jan., pp. 198-215, 2018.

FERNANDES, N. et al.,. Condicionantes Geomorfológicos dos Deslizamentos nas Encostas: Avaliação de Metodologias e Aplicação de Modelo de Previsão de Áreas Susceptíveis. Revista Brasileira de Geomorfologia, Volume 2, pp. 51-71, 2001;

FRAIFELD, F. \& FREITAS, M. M.,. Considerações geomorfológicas a respeito da corrida de massa do rio Vieira, Teresópolis - RJ. GeoPUC - Revista do Departamento de Geografia da PUC - Rio, July, 5(10), p. 16, 2013.

FRANK B., FORMIGA-JOHNSSON R.M., JAPIASSÚ VIANA V., IKEMOTO S.M. Disaster Risk Management in the State of Rio de Janeiro. In: Nehren U., Schlüter S., Raedig C., Sattler D., Hissa H. (eds) Strategies and Tools for a Sustainable Rural Rio de Janeiro. Springer Series on Environmental Management. Springer, Cham, 2019

GANEM, R. S. Gestão de Desastres no Brasil. Estudo. Consultoria Legislativa. Câmara dos, 2012. Available at http://www.terrabrasilis.org.br/ecotecadigital/images/gestao\%20ganem.pdf

GARCIA, C. \& FEARNLEY, C. J. Evaluating critical links in early warning. Environmental Hazards, 31 Jan., pp. 123137,2012

GOLNARAGHI, Maryam (Ed.). Institutional partnerships in multi-hazard early warning systems: a compilation of seven national good practices and guiding principles. Springer Science \& Business Media, 2012.

GUTIÉRREZ, A. P. A. et al.. Drought preparedness in Brazil. Weather and Climate Extremes, June, 3(1), pp. 95-106, 2014.

HERRMANN, M. L. D. P., MENDONÇA, M. \& CAMPOS, N. J., Avaliação das Enchentes e Deslizamentos Ocorridos em Novembro de 1991 e Fevereiro de 1994. Geosul (UFSC), Volume 16, pp. 46-79, 1994.

HORITA, F. E., ALBUQUERQUE, J. P. D., MARChEZINI, V. \& MENDIONDO, E. M. M., Bridging the gap between decision-making and emerging big data sources: an application of a model-based framework to disaster management in Brazil. Decision Support Systems, Volume 97, pp. 12-22, 2017.

HSIU-FANG, H., Three approaches to qualitative content analysis. Qualitative health research, 15(9), pp. 12771288, 2005.

IBGE - Instituto Brasileiro de Geografia e Estatistica. Pesquisa de Informações Básicas Municipais - MUNIC, 2009, Perfil dos Municípios Brasileiros: Assistência Social 2013. Diretoria de Pesquisas, Coordenação de População e Indicadores Sociais, 2013.

IBGE - Instituto Brasileiro de Geografia e Estatistica. Pesquisa de Informações Básicas Municipais - MUNIC, 2009, Perfil dos Municípios Brasileiros: Assistência Social 2017. Diretoria de Pesquisas, Coordenação de População e Indicadores Sociais, 2017.

JOHNSON, J. B.; REYNOLDS, H. T.; MYCOFF, J. D. Political science research methods. Cq Press, 2019.

KAPLOWITZ, Michael D. Statistical analysis of sensitive topics in group and individual interviews. Quality and Quantity, v. 34, n. 4, p. 419-431, 2000.

KULATUNGA, K. Structuring the unstructured data: the use of content analysis. Salford Quays, UK. , s.n., p. 13. 2007. 
LONDE, L., SORIANO, E., \& COUTINHO, M. Capacidades das instituições municipais de Proteção e Defesa Civil no Brasil: desafios e perspectivas. Revista Do Departamento De Geografia, 30, 77-95. https://doi.org/10.11606/rdg. v30i0.98715, 2015.

MACEDO, E. S. et al. Curso de treinamento de técnicos municipais para o mapeamento e gerenciamento de áreas urbanas com risco de escorregamentos e inundações. Cadernos de Estudos e Pesquisas (Universidade Salgado Oliveira), Volume 11, pp. 85-95, 2007.

MACHERERA, M. ; CHIMBARI, M. J. A review of studies on community based early warning systems. Jàmbá: Journal Of Disaster Risk Studies, v. 8, n. 1, 2016.

MARANDOLA, E. \& HOGAN, D. J., Vulnerabilidades e riscos:entre geografia e demografia. Revista Brasileira de Estudos da População, jan/jun, Volume 22, pp. 29-53., 2005.

MARCHEZINI, V. et al., Participatory Early Warning Systems: Youth, Citizen Science,and Intergenerational Dialogues on Disaster Risk Reduction in Brazil. Int J Disaster Risk Sci, December.8(1). 2017a.

MARCHEZINI, V. et al., Sistema de alerta de risco de desastres no Brasil: desafios à redução da vulnerabilidade institucional. In: Reduction of vulnerability to disasters: from knowledge to action. São Carlos: Rima, pp. 287-310. 2017b.

MASKREY, A.. Report on national and local capabilities for early warning. International Decade for Natural Disaster Reduction (IDNDR), 1997.

MCLINDIN, M. The Challenges Of Flood Warning Systems In The Developing World. Flood Risk Management: Global Case Studies of Governance, Policy and Communities, p. 115, 2019.

MINISTÉRIO DA INTEGRAÇÃO NACIONAL BRASIL,. Sistema Integrado de Informações sobre Desastres. [Online] Available at: https://s2id.mi.gov.br/ . Accessed 14 September 2017. 2017.

NUNES, L. H. 2009. Mudanças climáticas, extremos atmosféricos e padrões de risco a desastres hidrometeorológicos. População e mudança climática: dimensões humanas das mudanças ambientais globais, 53-73.

PELLERIN, J. R. G. M. et al. Les crues et laves torrentielles catastrophiques du 23 Décembre 1995 dans l'Etat de Santa Catarina (Brésil subtropical). Geomorphologie, Volume 1, pp. 51-60. 2002.

PORTAL FEDERATIVO, 2019. Alertas da Defesa Civil já chegam a 5,9 milhões de celulares em todo o Brasil. Available at: http://www.portalfederativo.gov.br/noticias/destaques/alertas-da-defesa-civil-ja-chegam-a-5-9-milhoes-decelulares-em-todo-o-brasil. Accessed 22 July 2019

RODRIGUES, A. et al., An Overview of Brazilian Scientific Production on Disasters. Desenvolvimento e Meio Ambiente, August, 34(1), pp. 61-73. 2015.

SAITO, S.M. Vulnerabilidades no contexto de sistemas de alerta de risco de desastres. Revista Gestão e Sustentabilidade Ambiental, v. 7, p. 618, 2018.

SÄTTELE, M., BRÜNDL, M. \& STRAUB, D. Quantifying the effectiveness of early warning systems. Natural Hazards Earth System Sciences, April, Volume 16, pp. 149-166. 2016.

SEDEC - Secretaria Nacional de Defesa Civil - S2iD. Available at: https://s2id-search.labtrans.ufsc.br. 2019 Accessed 1 August 2019.

SEIBOLD, E. Natural disasters and early warning. In: Early warning systems for natural disaster reduction. Springer, Berlin, Heidelberg, 2003. p. 3-10.

SORENSEN, J. H.,. Hazard warning systems: Review of 20 years of progress. Natural Hazards Review, pp. 119-125, 2000.

SORIANO, E. \& HOFFMANN, W.. The evolution of the protection systems against natural disasters in Brazil: laws, agencies, information and knowledge.. In: Management of Natural Disasters. Southampton: WIT Press, pp. 49-58. 2016. 
TATIZANA, C., OGURA, A. T., CERRI, L. E. \& ROCHA, M. C. M. Modelamento numérico de análise de correlação entre chuvas e escorregamentos aplicado às encostas da Serra do Mar, município de Cubatão.. São Paulo, s.n., pp. 237-248, 1987.

UNEP - UNITED NATIONS ENVIRONMENT PROGRAMME. Early Warning Systems: A State of the Art Analysis and Future Directions, Nairobi: s.n., 2012

UNISDR - UNITED NATIONS OFFICE FOR DISASTER RISK REDUCTION. [Online] Terminology. Available at: http:// www.preventionweb.net/english/professional/terminology/v.php?id=508. [Accessed 29 December 2017].

UNISDR - UNITED NATIONS OFFICE FOR DISASTER RISK REDUCTION. Early Warning - From Concept to Action: the Conclusions of the Third International Conference on Early Warning (EWC III). Bonn, s.n. 2006.

UNISDR- UNITED NATIONS OFFICE FOR DISASTER RISK REDUCTION Concept note Learning to live with risk -Disaster Risk Reduction to encourage Education for Sustainable Development. World Conference on Education for Sustainable Development (WCESD) 31 March - 2 April 2009, Bonn. Available at: https://www.unisdr.org/ files/0539_WCESDConceptNote.pdf

VALENCIO, N. F. L. d. S., Desastres: tecnicismo e sofrimento social. Ciência \& Saúde Coletiva, June, pp. 3631-3644. 2014.

VALENCIO, N. F. L. d. S., Sociologia dos desastres: construção, interfaces e perspectivas no Brasil. São Carlos: Rima. 2009.

WEICHSELGARTNER, J. \& PIGEON, P.. The role of knowledge in disaster risk reduction. International Journal of Disaster Risk Science, pp. 107-116. 2015.

WILDEMUTH, Barbara M. (Ed.). Applications of social research methods to questions in information and library science. ABC-CLIO, 2016. 